\title{
Lymph Node Disorder
}

National Cancer Institute

\section{Source}

National Cancer Institute. Lymph Node Disorder. NCI Thesaurus. Code C35346.

Any disorder of the lymph nodes. 